\title{
Male Reproductive System of Blue Swimming Crab, Portunus pelagicus (Linnaeus, 1758)
}

P. Soundarapandian*, D. Varadharajan and T. Anand

Faculty of Marine Sciences, Centre of Advanced Study in Marine Biology, Annamalai University, Parangipettai-608 502, Tamil Nadu, India.

\begin{abstract}
The male reproductive system of Portunus pelagicus is bilaterally symmetrical creamy to whitish in colour, composed of a pair of testes, a pair of vas deferentia and a pair of ejaculatory ducts internally and a pair of penes, pair of secondary pleopods and the pair of primary pleopods externally as accessory reproductive organs, present on the inner side of the abdominal flab. Vas deferentia consisted of three parts such as, Anterior (AVD), Median (MVD) and Posterior (PVD). The male gonad has different stages which is includes immature, maturing and matured. The gonadosomatic index of the male crab is increased from immature crabs to matured crabs $(0.66 \pm 0.08$ to $1.23 \pm 0.06)$. Fifty percent of the male crabs have attained sexual maturity when they reached the size of $10.6-11.0 \mathrm{~cm}$ carapace width.
\end{abstract}

Keywords: Copulatory organ; Vas deferens; Accessory glands; Pleopods; Blue swimmer crab

\section{Introduction}

In recent years crab becomes a most popular food items which command high prices in the national and international markets. The main species supporting the crab fisheries in India are Scylla serrata, Scylla tranquebarica, Portunus pelagicus, Portunus sanguinolentus, Charybdis feriata, Charybdis lucifera and Charybdis truncata. The Portuns pelagicus is one of the commercially important crabs along the Parangipettai coast and has a great demand for their esteemed seafood delicacy and also the value of fishery they support [1-3]. Due to their high demand in local and foreign markets they are heavily exploited from the Parangipettai coast $[1,2,4]$. For year round hatchery operation not only broodstock are important but also males. Therefore, the knowledge about the male reproductive system is very much essential to select the matured males for breeding. Hence in the present study an attempt was made on the various aspects of reproductive biology of male Portunus pelagicus, such as morphology and histology of the reproductive system, developmental stages of gonads, gonadosomatic index (GSI) and size at maturity.

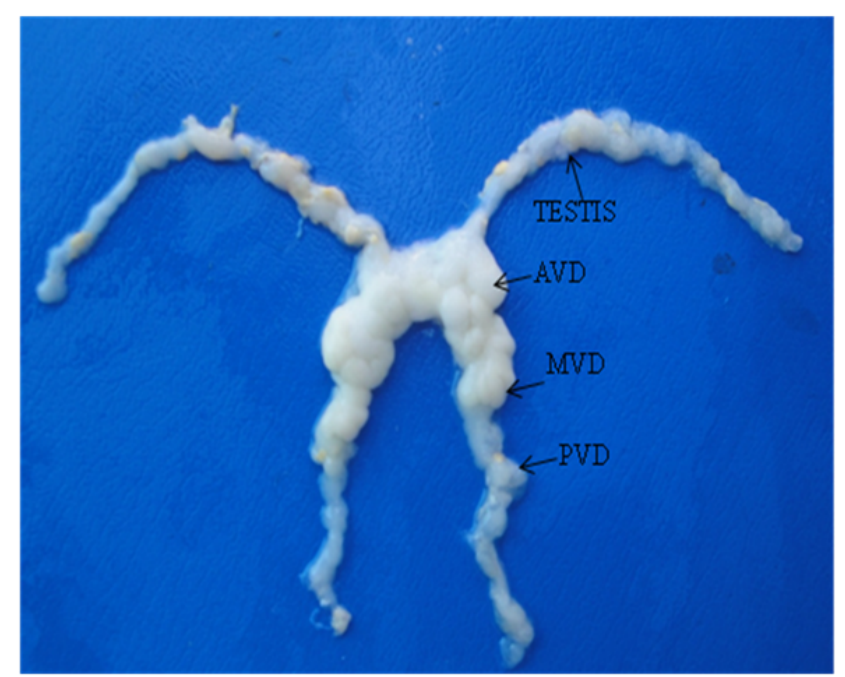

Figure 1: Image of male reproductive system of Portunus pelagicus.

\section{Materials and Methods}

Portunus pelagicus male crabs were collected from Parangipettai landing centre (Lat.11 $29^{\circ} \mathrm{N}$; Long. $79^{\circ} 46^{\prime} \mathrm{E}$ ) and brought to the laboratory by using plastic container with seawater. The crabs were cold-anesthetized by the ice and killed at $20^{\circ} \mathrm{C}$ during 10 minutes. Then the crabs were dissected to study the morphology and histology of the reproductive tract, size at sexual maturity, stages of maturation and gonadosomatic index (GSI). The gonads were fixed in alcohol-formalinacetic acid fixative in overnight. After being preserved in alcoholformalin-acetic acid for 24 hours, transverse sections of the gonads were dehydrated in graded ethanol, embedded in paraffin, sectioned at $\mu \mathrm{m}$ and stained with Haematoxlin and Eosin for histological examination. The sections were finally observed under the electron microscope and micrographs were taken. The size at maturity of the male crabs was calculated by the presence of spermatophores in the vas deferens of the crabs. The dissected gonads were measured to the nearest $0.001 \mathrm{~g}$ by using the electronic balance and subsequently gonadosomatic index was calculated by the following formula.

Wet weight of the gonad

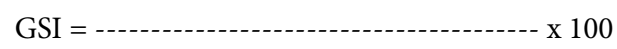

Wet weight of the animal

\section{Results}

\section{Morphology of the male reproductive system}

The male reproductive system of $P$. pelagicus is bilaterally symmetrical creamy to whitish in colour, composed of a pair of testes,

*Corresponding author: P. Soundarapandian, Faculty of Marine Sciences, Centre of Advanced Study in Marine Biology, Annamalai University, Parangipettai-608 502, Tamil Nadu, India; Tel: +91-04144-243223; Fax: 04144243553; E-mail: soundsuma@gmail.com

Received April 10, 2013; Accepted November 18, 2013; Published November 20, 2013

Citation: Soundarapandian P, Varadharajan D, Anand T (2013) Male Reproductive System of Blue Swimming Crab, Portunus pelagicus (Linnaeus, 1758). J Cytol Histol 5: 206. doi:10.4172/2157-7099.1000206

Copyright: (C) 2013 Soundarapandian P, et al. This is an open-access article distributed under the terms of the Creative Commons Attribution License, which permits unrestricted use, distribution, and reproduction in any medium, provided the original author and source are credited. 
Citation: Soundarapandian P, Varadharajan D, Anand T (2013) Male Reproductive System of Blue Swimming Crab, Portunus pelagicus (Linnaeus, 1758). J Cytol Histol 5: 206. doi:10.4172/2157-7099.1000206
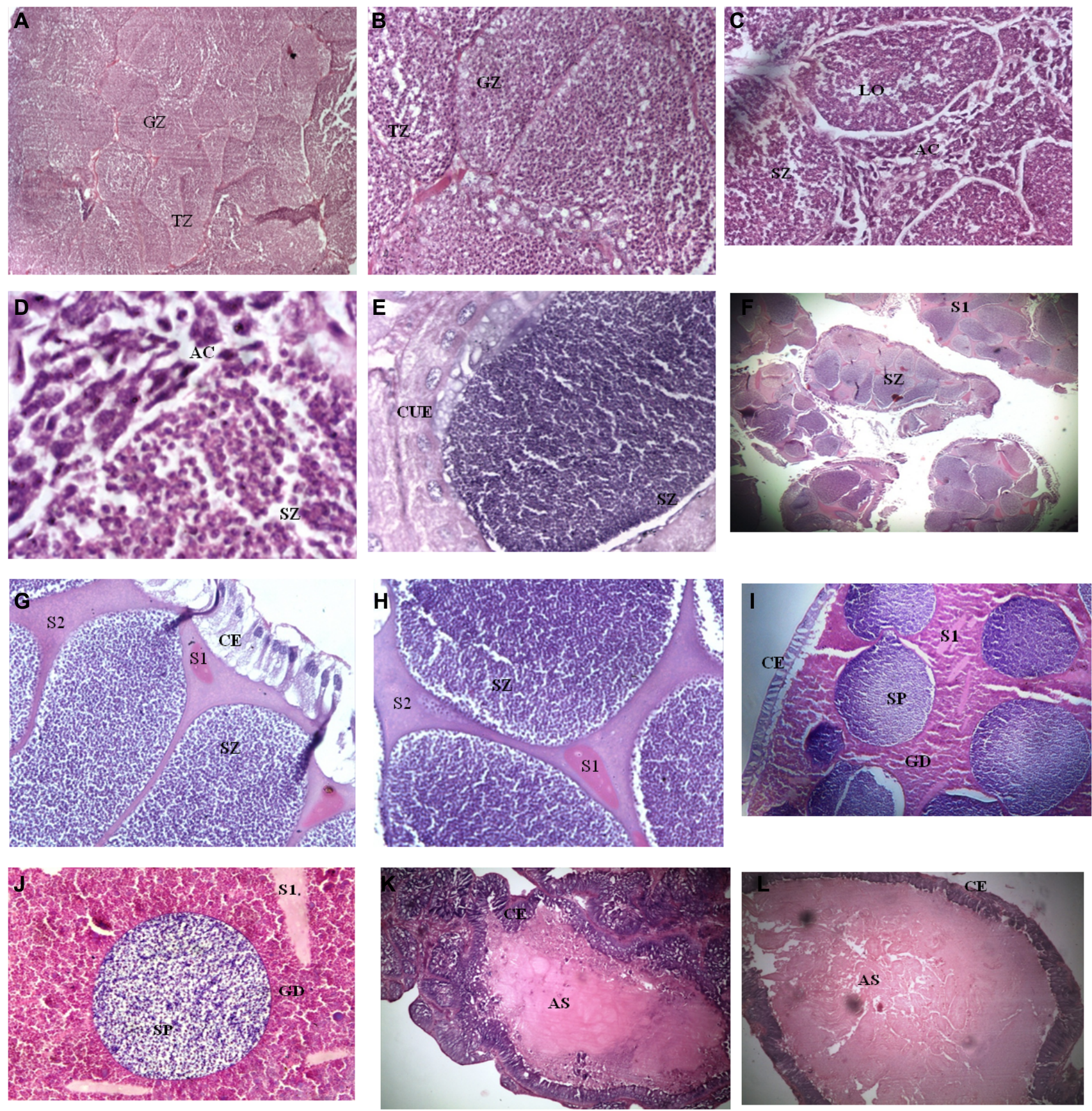

(GZ-Gerrminal Zone, TZ-Transformation Zone, LO-Lobules, SZ-Spermatozoa, AC-Accessory cells, CUE-Cuboidal epithelium, S1-Substance 1, S2-Substance 2 , CE-Columnar epithelium, SP- Spermatophore, GD-Granular droplets, AS-Agranular substance).

Figure 2: Histological sections of the male reproductive system.

a. Proximal testis transverse section $4 \mathrm{X}$.

b. Proximal testis transverse section 10X.

c. Distal testis transverse section 10X.

d. Distal testis transverse section 100X

e. Proximal anterior vas deferens cross section $40 \mathrm{X}$.

f. Distal anterior vas deferens transverse section $4 \mathrm{X}$.

g. Anterior vas deferens transverse section $40 \mathrm{X}$.

h. Anterior vas deferens transverse section $40 \mathrm{X}$

i. Proximal median vas deferens transverse section $10 \mathrm{X}$.

j. Distal median vas deferens transverse section 10X

k. Posterior vas deferens cross section $10 \mathrm{X}$

I. Ejaculatory duct cross section $10 \mathrm{X}$. 
a pair of vas deferentia and a pair of ejaculatory ducts internally and a pair of penis, pair of secondary pleopods and the pair of primary pleopods externally as accessory reproductive organs, present on the inner side of the abdominal flab. The testes are tubular and highly coiled roughly in the form of " $\mathrm{H}$ " located on the dorsal portion of the hepatopancreas sandwiched between the hepatopancreas and the hypodermis of the carapace, and continuing laterally to the stomach up to vas deferens. Just before the posterior stomach and anterior to the heart the left and right testis are bridged by a commissure. The testes are connected with the vas deferens through a short small duct called vas efferens. Vas deferentia is a pair of elongated and coiled tubules which extend longitudinally from the posterior testes upto the posterior region of the body. Vas deferentia is consisted of three distinct regions, Anterior (AVD), Median (MVD) and Posterior (PVD). The AVD appeared white, tightly coiled and lying on either side of the median line of cephalothorax posterior to the dorsal part of the stomach. The coils of the AVD increase in size posterio-ventrally and lead into the middle vas deferens, which appear like milky-white meandering tubules of a higher caliber than both the testes and AVD. The posterior vas deferens appeared in whitish transparent colour arises from the posterior end of the median vas deferens, that is a massive for its proximal part, but gradually narrow before opening to the ejaculatory duct. Each posterior VD was connected with an ejaculatory duct, which is a smooth narrow duct extending between the musculature of the swimming peddles. The ejaculatory duct leads into the slender weak tube like genital papilla (or) penis, which are located at the base of the swimming legs. Each penis passes into the two pairs of abdominal appendages called pleopods (or) gonopods situated in the inner side of the abdominal flab. The first pleopod is made up of two segments, the basal one is broad to the sternal wall and the terminal one is long tube-like and tapering towards the tip, which is actually inserted into the seminal receptacle of the female during copulation. The second pleopod helps in passing the seminal fluids from the penis into the funnel like portion of the first pleopod (Figure 1).

\section{Histology of the male reproductive system}

Testes: Testes are tubular organs, consisting of microscopically visible testicular lobules, which were connected to the central seminiferous duct. Each testicular lobule is surrounded by an outer layer of thin connective tissue and an inner layer of epithelium. The lumen of the lobules contains generative cells and/or their progeny (Spermatogonia, spermatocytes, spermatids and spermatozoa) along with accessory cells (Figure 2d). The lobules consist of two different regions that are proliferation region and transformation region. Essentially peripheral region of the lobules consisted of spermatogonia and accessory cells which arise from the wall of testicular lobules in the proliferation region. Accessory cells look small with oval nuclei located between the spermatogonia. These cells are distinguishable from the spermatogonia because of their nuclei which seem to be more basophilic, larger than those of the spermatogonia and deeply stained than the nuclei of other cells of the lobules (Figure 2c).

The transformation region observed with germinal cells in the different stages of spermatogenesis and spermiogenesis are accompanied by accessory cells. Although cells at all stages can be seen along the testis, cells belonging to the same transversal section are usually in the same stage of development. Mature sperm are typically found in the center of the testicular lobes near to seminiferous duct. An epithelium encloses the seminiferous duct except where it faces the testicular lobes, which open broadly into the ducts allowing passage of mature sperm to the ducts. Only mature spermatozoans are found in the seminiferous duct, which gradually becomes a short, muscular structure called vas efferentia delivering spermatozoa to the anterior vas deferentia (AVD) (Figure 2a-d).

\section{Vas deferens}

Anterior Vas Deferens (AVD): The spermatozoa accumulated in the seminiferous duct of the testis are transferred to the vas deferens where they are packed and stored in spermatophores and then ejaculated through the ejaculatory duct. The histological structure of the AVD changes along its length although it is composed of three basic layers: an outer covering of connective tissue, a middle muscular layer, and an inner epithelial lining. These layers are also present in the MVD and the PVD. Spermatozoa from the distal region of the testis enter the AVD as homogeneous mass, which is divided in to spermatophores by two consecutive epithelial secretions. The first substance named substance I is secreted by the epithelium of the proximal portion of the AVD. Substance I has a homogeneous appearance, agranulated, stains red in hematoxylin-eosin and Mallory's stain, and divides the sperm mass into small oval groups of irregular size. The second substance, substance II, is secreted by the distal portion of the AVD, stains blue in Hematoxylin-eosin and Mally's stain, and surrounds each single spermass, which becomes a spermatophore. Freshly formed spermatophores are found along the distal portion, of AVD. Spermatozoids without spermatophores are also present in its lumen. The epithelium is composed of a single layer of secretary columnar cells in the proximal portion of AVD that decrease in size towards the distal portion (Figures 2e-h)

Median Vas Deferens (MVD): The most proximal portion of the MVD is initially similar to the distal portion of the AVD in their histological features although the epithelium gradually becomes less elongated so that it approaches a cuboidal type epithelium. There appear to be little glandular activity in the mid-region of the MVD. The muscular layer is also thinner. The size of the lumen is increased than in the AVD, which are filled with the scattered spermatophores liberated from the AVD and granular luminal spherical droplets that are closely packed around spermatophores. As the spermatophores are stored in MVD they become spherical or oval in shape with varies in size (Figures $2 \mathrm{i}$ and $\mathrm{j}$ ).

Posterior Vas Deferens (PVD): The connective tissue and the muscular layer are thicker than in the MVD. The epithelial layer consisted of small columnar cells showing numerous infolding into the lumen. The lumen was filled with viscid eosinophilic agranular substance with few ovoid spermatophores (Figure 2k).

Ejaculatory Duct (ED): The connective tissue layer and muscular layer were thicker than those found in the PVD. The epithelial layer formed of columnar cells with indefinite boundaries. Lumen was found filled with agranular substance and similar to that in the PVD (Figure $21)$.

\section{Developmental stages of male gonads}

Immature: The gonads of the immature crabs were small, and creamy in colour, lying on the either side of the stomach. Testes and vas deferentia are not clearly differentiated. Crab having carapace length below $9.5 \mathrm{~cm}$ showed immature gonads.

Maturing: Testes and vas deferentia are well developed and clearly differentiated, and creamy white in colour. Testes appeared as large coiled tube which spreading laterally and posteriorly to the stomach. 
Citation: Soundarapandian P, Varadharajan D, Anand T (2013) Male Reproductive System of Blue Swimming Crab, Portunus pelagicus (Linnaeus, 1758). J Cytol Histol 5: 206. doi:10.4172/2157-7099.1000206

Anterior vas deferentia becoming are enlarged middle and posterior vas deferentia straight and opaque extending to both the sides of the heart.

Matured: Testes showed further enlargement, as vas deferentia are coiled and very much swollen occupying full body cavity. The AVD and MVD were enlarged and appeared in milky white colour, PVD enlarged and convoluted but still opaque. Gonads obtained from males measuring above $11.0 \mathrm{cc}$ carapace width showed mature stage.

Gonadosomatic index (GSI) in male crabs: The gonadosomatic index was increased from immature to matured crabs $(0.66 \pm 0.08$ to $1.23 \pm 0.06)$. The size of the animals is ranging between $8.5-9.0 \mathrm{~cm} \mathrm{CW}$ to $14.6-15.0 \mathrm{~cm} \mathrm{CW}$ (Table 1).

Size at first maturity: Fifty percent of the male crabs are attained sexual maturity when they reached the size of $10.6-11.0 \mathrm{~cm}$ carapace width.

\section{Discussion}

The morphology of the male reproductive system of Portunus pelagicus consisting of an " $\mathrm{H}$ " shaped structure with a pair of testes, pair of vas deferentia and ejaculatory ducts was similar to the reproductive systems described for other decapod crustaceans $[5,6]$ and portunid crabs in particular [7-11]. The descriptions of the testes and commissure of Portunus pelagicus matched the descriptions of Pachigrapsus marmaratus [12], Portunus sanguinolentus [8], Callinectes sapidus [13], Thenus orentalis [14], Panulirus laevicauda [15] and Goniopsi cruentata [10]. However, Beninger et al., Beninger et al., Simeo et al. [16-18] did not report the existence of a commissure between the testes of Chionoecetes opilio and Maja branchyodactyla respectively. Testes of Portunus pelagicus are tubular organs composed of numerous microscopically visible lobules connected to the semniferous duct; consequently, they have been classified as lobular testes according to the categories (lobular and tubular) established by Nagao and Munehara [19] and are similar to the previous reports of some other brachyurans $[8,9,20,21]$. However in some species of brachyura have tubular testes, such as Menippe mercenaria [22], Eriocheir sinensis [23], Chionoecetes opilio [24,25], Pachygrapsus crassipes [26] and Chionoecetes bairdi [25]. Moreover, the tubular testes also reported in different groups of Brachyura (Majoidea, Grapsoidea, and Xanthoidea). Adiyodi and Anilkumar [27]stated that lobular testes are very common in portunid crabs. Some brachyurans have a tubular testicular arrangement whilst others have a lobular one,

\begin{tabular}{|c|c|c|c|}
\hline $\begin{array}{c}\text { Carapace width } \\
(\mathbf{C m})\end{array}$ & $\begin{array}{c}\text { Mean body weight } \\
\mathbf{( g )}\end{array}$ & Mean gonad weight $\mathbf{( g )}$ & GSI \\
\hline $8.5-9.0$ & $42.08 \pm 2.05$ & No signs of gonad & - \\
\hline $9.1-9.5$ & $48.1 \pm 2.83$ & No signs of gonad & - \\
\hline $9.6-10.0$ & $55.62 \pm 3.09$ & $0.36 \pm 0.04$ & $0.66 \pm 0.08$ \\
\hline $10.1-10.5$ & $62.5 \pm 4.20$ & $0.47 \pm 0.07$ & $0.76 \pm 0.16$ \\
\hline $10.6-11.0$ & $73.25 \pm 8.13$ & $1.19 \pm 0.14$ & $1.53 \pm 0.27$ \\
\hline $11.1-11.5$ & $88.7 \pm 8.99$ & $1.42 \pm 0.20$ & $1.61 \pm 0.24$ \\
\hline $11.6-12.0$ & $112.7 \pm 4.71$ & $1.88 \pm 0.15$ & $1.68 \pm 0.18$ \\
\hline $12.1-12.5$ & $124.5 \pm 4.80$ & $2.14 \pm 0.25$ & $1.81 \pm 0.09$ \\
\hline $12.6-13.0$ & $130.11 \pm 17.34$ & $2.42 \pm 0.29$ & $1.86 \pm 0.14$ \\
\hline $13.1-13.5$ & $142.03 \pm 22.96$ & $2.40 \pm 0.44$ & $1.73 \pm 0.41$ \\
\hline $13.6-14.0$ & $156.5 \pm 8.18$ & $2.41 \pm 0.14$ & $1.53 \pm 0.03$ \\
\hline $14.1-14.5$ & $181.8 \pm 25.65$ & $2.66 \pm 0.15$ & $1.48 \pm 0.13$ \\
\hline $14.6-15.0$ & $220.5 \pm 5.50$ & $2.71 \pm 0.17$ & $1.23 \pm 0.06$ \\
\hline
\end{tabular}

Table 1: Mean body weight, mean gonad weight, gonadosomatic index (GSI) of the male crab (Values are expressed as Mean \pm SD). is unknown [16-18]. The testes connected to the vas deferens by means of a small duct known as vas efferens has been described in Callinectes sapidus [20] and Portunus pelagicus [9]. Vas deferens (VD) is a pair of elongated and convoluted tubules which extend longitudinally in the posterior region of the body $[8,28]$. In Portuns pelagicus the vas deferens was divided into three distinct regions, the anterior, middle and posterior vas deferens as has been reported in other crabs based on their morphological and functional criteria in Portunus sanguinolentus [8,29], Callinectes sapidus [13], Thenus orentalis [14] and Maja branchydactyla [18]. However in other studies characterized two in Goniopsis cruentata [10], four in Synalpheus chacei [35] and Diogenes puligator into as many as eight regions [33]. Different criteria and different microscopic and macroscopic foci may account for this diversity [10]. The presence of diverticula in the VD of brachyuran has been widely described $[8,10,18]$, particularly in spider crabs, which had numerous ramified diverticula in the posterior region of the VD [12]. Diverticula play an important role in increasing the secretion, absorption and storage of spermatophores and seminal fluids $[27,30]$. The terminal portion of the reproductive system is the ejaculatory duct, which is a smooth duct extending between the musculature of the swimming pedals, as already described in Brachyura [5]. The microscopic structure of the testis in Portunus pelagicus is, in general terms, very similar to the structure described for other decapods [5,31]. The testes are formed by seminiferous tubules and, like most Decapoda; the spermatogonia are located in the most peripheral portion of this tubule [32] while developing gametic cells fill the central region [8]. The seminiferous tubules are composed of accessory cells and generative cells, which are derived from the progenitor cells inside the wall of tubules. The wall of the tubules is composed of one or more layers of connective tissue in decapods [5]. Accessory cells of Portunus pelagicus are located in the wall of the tubules and can be distinguished from generative cells by their deeply stained flattened nuclei. Interestingly, prominent accessory cells present a radial disposition with a large cytoplasmic prolongation towards the central region of the seminiferous tubule.

The vas deferens is divided into three different structural regions according to their different synthetic activities (Anterior, median and posterior vas deferens). These epithelial regions are responsible for the formation of a spermatophore, which is species-specific; the transportation of the spermatophore to the gonopore; and the maintenance of sperms until fertilization [33]. According to Hinsch and Walker [34], sperm maturation, spermatophore formation and seminal fluid production and storage all took place in the vas deferens of crustaceans. Burton [14] found that the vas deferens stored spermatozoa from the testes for maturation and nourishment before ejaculating them. Binford [22] described the vas deferens as a rectilinear structure lined with columnar epithelium secreting the substances required to produce the wall of the spermatophore. Cronin [20] observed that most of the anterior part of the vas deferens was involved in the secretion of substances required to envelop and storing spermatophores. Hinsch and Mcnight [35] also attributed early spermatophore formation and seminal fluid production to this region. However, Sainte Marie G and Sainte Marie B [36] did not consider sperm leaving the testes and entering the vas deferens to be fully developed spermatozoa, but suggested these cells completed their maturation inside the spermatheca. Accordingly, the appropriateness of the term "Vas deferens" was questioned and was suggested reconsidering its use for branchyuran crustaceans [36]. At the end of spermatogenesis, the sexual cells are transported to the vas deferens, where the spermatic cells are encapsulated, forming spermatophores $[35,36]$. The vas deferens functions to pack the spermatozoa into spermatophores which protect them against 
desiccation and microbial infection, among other functions. Upon exit from the testis into the vas deferens, the spermatozoa are surrounded by epithelial secretions that consolidate the sperm mass and develop the noncellular spermatophore wall layers [37-39]. In Portunus pelagicus the secretions of the AVD are involved in the spermatophore formation: substance I, secreted by the epithelium of the proximal portion, divides the sperm mass into small clumps; and substance II, secreted by the epithelium of the distal portion, consolidates the small clumps resulting into the spermatophore. This pattern has been also observed in several brachyurans $[5,18,27]$, in which 2 substances of different nature secreted in the AVD are responsible for the spermatophore formation. These two types of substances and although differentially described have been observed in Scylla serrata [40], Chionoecetes opilio [36], Goniopsis cruentata [10], and in Maja brachydactyla [5] tend to be comprised of rod-shaped glycoprotein and polysaccharide chains, apparently originating from the columnar epithelium of the vas deferens. A distinctive, single, envelope layer was present around the spermatophore which appeared to be deposited in the initial section of the anterior vas deferens. This envelope layer has been reported in Portunus sanguinolentus [8], Geryon fenneri [41], Scylla serrata [42], Chionoecetes opilio [16] and in Pseudocarcinus gigas [43]. An aggregation of sperm cells without an envelope layer has been reported in several species including the spanner crab, Ranina ranina [8]. In the AVD and MVD, the musculature may be related to spermatophore formation and movement; since muscular contractions may separate the sperm mass [8], contribute to the movement of the spermatophore towards posterior regions, and mold the spermatophore by rotation [12].

The spermatophores of Portunus pelagicus are typical of brachyuran crabs $[27,39,44]$ as they are spherical or ellipsoid, nonpedunculate and vesicular, unlike anomuran spermatophores [40,43]. In a study involving the species Scylla serrata, the spermatophores were described as uniform in structure, and triangular or spherical in shape [40]. In the present study similar spermatophore shape was observed but these changed during progression through the vas deferens. The size of the spermatophore is also varied in diameter. The size of the spermatophores is similar to those found in Callinectes sapidus [13] and Portunus sanguinolentus [8]. The form of spermatophore varies depending on the shape and contraction of the lumen of vas deferens and the accumulation of the acellular materials in the spermatophore layers [5]. In Portunus pelagicus the histological sections of spermatophore consists of a sperm mass enclosed by a single layer of smooth acellular thick spermatophores wall is similar to Libinia emarginata and Libinia dubia [34], Ovalipes ocallatus [45], Maja brachydactyla [18] and in Portunus pelagicus [46]. In contrast the smear preparation of the spermatophore is enclosed by double layered spermatophore wall whereas in other species of brachyurans [20] and also stated in Portunus pelagicus [41]. This variation within a species is may be due to dehydrations of gonad tissues with increasing concentration of ethanol during histological sample preparation. In the present study the outer surface of the spermatophore is smooth membranous layer in both histological and smear preaparation is similar to Carcinus maenas [47], Libinia emarginata and Libinia dubia [34], Ovalipes ocallatus [45], Goniopsis cruentata [10] and Maja brachydactyla [18]. In contrast, a convoluted surface has been reported in Portunus pelagicus [48] and Metopograpsus messor [49]. The snow crab Chionoecetes opilio [50] presents two spermatophore wall morphologies, smooth and convoluted, produced by males in different developmental stages of sexual maturity.

In decapods, spermatophore storage is variable. In most of the brachyurans are store spermatophores in the MVD. There is an interspecific variation in some species of brachyurans, which storing spermatophores in the PVD (e.g. Libinia emarginata [34] and [51] Uca lacteus). The medial portion of the vas deferens (MVD) is known for its secretory activity [10] however in Scylla serrata the MVD has no secretory activity [52]. The size of the epithelium decreases from the proximal portion of the AVD, with columnar cells, to the MVD, which presents flattened cells. The decrease of the epithelium has been also observed in Callinectes sapidus [20] and Chaceon fenneri [41], although the general pattern among brachyurans is a constant height along the VD. Sapelkin and Fedoseev [25] pointed out that the secretory activity, the amount of sexual products accumulated in the lumen, and the location of the cells may affect the height of the cells. In Portunus pelagiucs, the decrease in height of the epithelium along the AVD and MVD may be related to a decrease in secretory activity, since the main role of the MVD is the storage of spermatophores as in Maja branchydactyla [18]. In addition, the epithelial cells of the MVD in Libinia emarginata and Libinia dubia absorb the secretion products of the AVD, as indicated by the numerous micropinocytotic vesicles at the cell surface [34]. However, in the present study no absorption activity was reported, since micropinocytotic vesicles were not observed and the secretions of the AVD remain embedded between the secretions of the MVD as in Maja branchydactyla [18].

The posterior vas deferens seems to present a great variability of functions among brachyurans [18]. The PVD is characterized by the presence of invaginations in its wall. In Portunus pelagicus the epithelial layer of the PVD secretes agranular substances that are filled in the luman is similar to earlier report in Scylla serrata [52] and in Pseudocarcinus gigas [43]. In contrast, the PVD are filled with luminar agranular substances with few ovoid spermatophores in it. Thus, the epithelium of the PVD in Libinia emarginata and Libinia dubia presents secretory activity and an ultrastructure similar to that in the AVD and MVD [34], whereas the PVD in Chionoecetes opilio presents a phagocytic role of spermatophores and spermatozoa in the distal portion and a storage function of seminal fluids in the proximal region [53]. The epithelial layer of the PVD absence of secretory activity is in agreement with its role mixing spermatophores and seminal fluids of the PVD in Maja brachydactyla [18]. The ED transfers the spermatophore masses from the VD to the gonopore during copulation, as in other brachyurans [20]. The wall of the ED is composed of 3 layers: a connective tissue layer; a muscular layer; and an internal epithelium. The epithelial layer composed of cuboidal epithelial cells. Whereas in portunid crabs Callinectes sapidus [20],Portunus sanguinolentus [8] and the Majoidea Libinia emarginata and Libinia dubia [34] present cuboidal or low columnar cells. The lumen of the ED is filled with epithelial cells, although the remainder of the secretions from the accessory gland and a few spermatophores can eventually be seen. Similar findings have been described in Ericheir sinensis [23], Portunus sanguinolentus [8], Scylla serrata [52], Goniopsis cruentata [10] and Ucides cordatus [11], whose ED contains material similar to that secreted in the PVD and the spermatophores. [52] identified a fourth luminal secretion in the ED, which they labelled " $D$ ". In Portunus pelagicus, the luminal substance in the ED appeared to be the same as that in PVD ("C") and there appeared to be no justification to classify them separately based on histology alone as in Pseudocarcinus gigas [43]. The musculature may play an important role in the extrusion by allowing the dilatation of the lumen, normally closed by the epithelium, and subsequently, the movement of spermatophores embedded in seminal fluids to the gonopore. The muscular layer of the ED is increased when compared to PVD in Portunus pelagicus. Similar condition was observed in Ranina 
Citation: Soundarapandian P, Varadharajan D, Anand T (2013) Male Reproductive System of Blue Swimming Crab, Portunus pelagicus (Linnaeus, 1758). J Cytol Histol 5: 206. doi:10.4172/2157-7099.1000206

ranina [54]. In contrast the musculature decreases in Chionoecetes opilio and Chionoecetes bairdi [25], whereas the muscular layer is constant in Maja branchydactyla [18]. The ED presents a type of tissue, identified as the androgenic gland (AG), attached to the musculature by connective tissue. The AG is responsible for the secretion of the androgenic gland hormone, which maintains and develops the male sexual characters [55]. The AG appears as a triangular organ in a cross section of the $\mathrm{ED}$ and is composed of a cellular mass surrounded by connective tissue. The cells are irregular or polygonal with a central nucleus and vacuoles in the cytoplasm, and only a few cells appear binucleate. Similar descriptions of the AG have been previously reported in Maja brachydactyla $[18,56,57]$.

Very few works have been described for the maturity stages in male crabs. Haefner [58] has described six maturity stages in the males of Cancer irroratus. Campbell and Eagles [59] observed five stages of maturation in Cancer iroratus based on a modified version of Haefner [58] who indicated six stages of gonad development. Corgos and Freire [60] reported four different morphometric categories of male gonads in Maja brachydactyla. Sukumaran and Neelakantan [61] recognized three stages of maturation based on the testis development in Portunus pelagicus and Portunus sanguinolentus. In Portunus pelagicus three stages of maturation was reported based on the development of vas deferens by [62]. The GSI in females showed clear cyclic pattern with high values during January - February in Portunus sanguinolentus and during September and January - February in Portunus pelagicus [61]. In the present study the GSI was studied only based on the size and weight of the crab but not in seasonal wise. The GSI has the great relationship with the size and weight of the crabs. The reproductive capacity of certain crustacean species can be assessed by the study of sexual maturity [63]. The size at onset of sexual maturity in brachyurans can be evaluated considering different criteria, including growth allometry, gonad development stages, presence of spermatic bags or sperm in spermathecas, vestige eggs on the ovigerous areas or the presence of eggs in the abdomen as was analyzed by several authors Charniaux-Cotton et al., Lopez Greco and Rodriguez, Pinheiro and Fransozo, Muino et al., [59,64-66].Sexual maturity in brachyurans has been determined in various ways, based on the analyses of morphological maturity, relative growth criteria and physiological and functional maturity [67]. According to Hartnoll [68], the consecutive changes observed during gonadal development are important because besides enabling and estimate of physiological sexual maturity $[69,70]$. In brachyuran crabs chela in males and abdomen in females are considered as secondary sexual characters because of their functions in reproduction [71]. The male crab uses its chela for territorial defense, combat, mating and courtship as well as in carrying and holding the female during copulation. The abdomen in adult females forms an incubation chamber for the developing eggs, which are attached to the setose pleopods. The increase in relative growth of the male chela and female abdomen at the puberty moult brings these structures to full functional size at sexual maturity. Hence the relative growth of chela in males and abdomen in females has been used to determine size at which puberty moult occurs or functional maturity attained. Pillai and Nair [72] from Cochin, west cost of India reported that the size of the smallest berried Portunus sanguinolentus at $8.5 \mathrm{~cm}$ CW and the size at maturity range was $8.1-9.6 \mathrm{~cm}$ CW. Sumpton et al. [73], who worked out physiological maturity in both male and female Portunus sanguinolentus from Queensland, Australia, reported that the males and females attain sexual maturity at 8.3 and $7.4 \mathrm{~cm}$ CW respectively. Reeby et al. [74], reported that male Portunus sanguinolentus attains full sexual maturity (meaning functional as well as physiological) at $8.1-8.5 \mathrm{~cm}$ CW from Karwar, west cost of India. They did not work out sexual maturity in Portunus sanguinolentus.

In south west coast of India the male and female may undergo a pupertal moult at a size ranging between $8.0-8.5 \mathrm{~cm}$ and $8.0-9.0 \mathrm{~cm}$ CW respectively. Rasheed and Mustaquim [75] reported that male and female attain full maturity at $8.3-8.9 \mathrm{~mm} \mathrm{CW}$ and $8.1-9.3 \mathrm{~mm}$ $\mathrm{CW}$, respectively. In the present study the male crab attained sexual maturity when those reached the size of $10.6-11.0 \mathrm{~cm}$ CW. According to the present investigation it was observed that the functional and physiological maturities occur almost at the same size. The size at which maturity occurs can vary with latitude or location [61] and within individuals at any location. Halawa and Efrizal [76] compared geographic variation in the size of sexually mature females in five species of crabs along the east and west coast of North America. Four of the five species show significant geographic variation in size at onset of maturity. The differences in size at maturity among population of the same species of crab may be attributed to variation in moult increment and in the number of moults [76,77]. Environmental factors such as temperature and salinity can also affect size at sexual maturity in crabs. Fisher [78], who investigated the effect of temperature and salinity on size at sexual maturity of female blue crab Callinectes sapidus from nine Texas bay systems stated that size at maturity can vary along the Texas coast, as temperature and salinity vary from bay to bay. He also mentioned that seasonal and annual variation in temperature and salinity in the bay could also affect size at onset of maturity.

\section{References}

1. Ananad T, Soundarapandian $P$ (2011) Sea ranching of commercially important blue swimming crab Portunis pelagicus (Linnaeus) in Parangipettai coast. Inter J Sci Nat 2: 215-219.

2. Varadharajan D, Soundarapandian P, Dinakaran GK, Vijakumar G (2009) Crab Fishery Resources from Arukkattuthurai to Aiyammpattinam, South East Coast of India. Curr Res J Biol Sci 1: 118-122.

3. Saradha PT (1998) Crab fishery of the Calicut coast with some aspects of the population characteristics of Portunus sanguinolentus, Portunus pelagicus and Charybdis cruciata. Indian J Fish 45: 375-386.

4. Sukumaran KK, Telang KY, Thippeswamy D (1986) On the fishery and biology of the crab Portunus pelagicus (Herbst) along the south Kanara coast. Indian J Fish 33: 188-200.

5. Krol RM, Hawkins WE, Overstreet RM (1992) Reproductive components. In Harrisson, F.W and Humes, A.G. (Eds.). Microscopic anatomy of invertebrates. Decapod Crustacea: Wiley-Liss. Inc.

6. Almeida AO, Buckup L (1999) Caracteres sexuais primaries e secundários do lagostim Parastacus defossus Faxon 1898 (Crustacea, Parastacidae). Nauplius 7: 113-126.

7. Estampador EP (1949) Scylla II. Comparative studies on spermatogenesis and oogenesis. Phil J Sci 78: 301-353

8. Ryan EP (1967) Structure and function of the reproductive system of the crab Portunus sanguinolentus (Herbst) (Branchyura: Portunidae). 11. The female system, Proceedings of the Symposium of the crustacea, Mar Biol Assoc India Symp Ser 2:522-544

9. George MJ (1963) Biology of the edible crab Neptunus sanguinolentus Herbst University of Madras, Madras, India. M.Sc Thesis 199.

10. Garcia T, Silva J (2006) Testis and vas deferens morphology of the red-clawed mangrove tree crab Goniopsis cruentata (Latreille, 1803). Braz Arch Biol Tech 49: 339-345.

11. Castilho G, Ostrensky A, Pie M, Boeger W (2008) Morphology and histology of the male reproductive system of the mangrove land crab Ucides cordatus (L) (Crustacea, Brachyura ocypodidae). Acta Zool 89: 157-161.

12. Mouchet S (1931) Spermatophores des Crustaces Decapodes Anomures et Branchyoures et castration parasitaire chez quelques pagures, Ann Sta Oceanogr Salammbo 6: 1-203. 
Citation: Soundarapandian P, Varadharajan D, Anand T (2013) Male Reproductive System of Blue Swimming Crab, Portunus pelagicus (Linnaeus, 1758). J Cytol Histol 5: 206. doi:10.4172/2157-7099.1000206

13. Johnson PT (1980) History of the blue crab, Callinectes sapidus, a model for the decapoda. Praeger Publishers, New York 440.

14. Burton TE (1995) The spermatid pathway and associated reproductive structures of squat lobster Thenus orientalis (Lund, 1793). Invert Reprod Develop 28: 53-61.

15. Lima AVP (1995) Estudo do Sistema Reprodutivo de machos da lagosta verde Panulirus laevicauda (Latreille, 1817) (Decapoda: Palinuridae). Paraíba: Universidade Federal da Paraíba. Dissertacao de Mestrado 200.

16. Beninger $P$, Elner R, Foyle T, Odense $P$ (1988) Functional anatomy of the male reproductive system and the female spermatheca in the snow crab Chionoecetes opilio (O. Fabricius) (Decapoda: Majidae) and a hypothesis for fertilization. J Crust Biol 8: 322-332.

17. Beninger P, Lanteigne C, Elner R (1993) Reproductive processes revealed by spermatophore dihiscence experiments and by histology, ultrastructure, and the histochemistry of the female reproductive system in the snow crab Chionoecetes opilio (O. Fabricius). J Crust Biol 13: 1-16.

18. Simeó CG, Ribes E, Rotllant G (2009) Internal anatomy and ultrastructure of the male reproductive system of the spider crab Maja brachydactyla (Decapoda: Brachyura). Tissue Cell 41: 345-361.

19. Nagao J, Munehara $\mathrm{H}$ (2003) Annual cycle of testicular maturation in the helmet crab Telmessus cheiragonus. Fish Sci 69: 1200-1208.

20. CRONIN LE (1947) Anatomy and histology of the male reproductive system of Callinectes sapidus Rathbun. J Morphol 81: 209-239.

21. Gupta RS, Chatterjee NB (1976) Anatomical observations of the internal male reproductive organs of Scylla serrata (Forskal). Ind Physiol Allied Sci 30: 34-42.

22. Binford $R$ (1913) The germ-cells and the process of fertilization in the crab Menippe mercenaria. J Morphol 24: 147-201.

23. Hoestlandt H (1948) Recherches sur la biologie de I' Eriochier sinensis en France. Ann Ins Oceanogr 24: 1-116.

24. Kon T, Honma $Y$ (1970) Studies on the maturity of the gonad in some marine invertebrates-IV: seasonal changes in the testes of the Tanner crab. Nippon Suisan Gakkai Shi 36: 1028-1031.

25. Sapelkin AA, Fedoseev VY (1981) Structure of male reproductive system of Tanner crabs. Sov J Mar Biol 7: 37-43.

26. Chiba A, Kon T, Honma $Y$ (1992) Structure of male reproductive system of Tanner crabs. Structure of male reproductive system of Tanner crabs. Acta Zool 73: 103-108.

27. Adiyodi KG, Anilkumar G (1988), Accessory Sex Glands In: Adiyodi, K.G and Adiyoedi, R.G. (Eds). Reproductive biology of Invertebrates Vol. 3, John Wiley and Sons. Kerala 261-318.

28. McLaughlin PA (1983) Internal anatomy. The Biology of Crustacea. 5: Academic Press. New York. 51-52.

29. Boopathi $A$ (2011) Reproductive biology of the commercially important Portunid crab Portunus sanguinolentus (Herbst). M.Sc. Dissertation, Annamalai University, India. pp 1-44

30. Diesel R (1991) Sperm competition and the evolution of behavior in Branchyura with special reference to spider crabs (Decapoda: Majidae), Bauer, R.T and Martin, J.W. (Eds.) Columbia University Press, New York. J Crustacean Sexual Biol 145-163

31. Taketomi Y, Nishikawa S, Koga S (1996) Testis and androgenic gland during development of external sexual characteristics of the crayfish Procambarus clarkii. J Crust Biol 16: 24-34.

32. Mota-Alves MI, Tome GS (1966) Estudo sobre as gonadas da lagosta Panulirus laevicauda (Latreille). Arquivos da Estacao de Biologia Marinha da Universidade Federal do ceara 6: 1-9.

33. Manjoncabeza ME, Raso JEG (2000) Morphological reproductive aspects of males of Diogenes pugilator (Roux, 1829) (Crustacea, Decapoda, Anomura) from southern Spain. Sarsia 85: 195-202.

34. Hinsch GW, Walker MH (1974) The vas deferens of the spider crab, Libinia emarginata. J Morphol 143: 1-19.

35. Hinsch GW, Mcnight CE (1988) The vas deferens of spanish lobster, Scyllarus chacei. Int. J Invert Reprod Dev 13: 267-280.
36. Sainte Marie G, Sainte Marie B (1999) Reproductive products in the adult snow crab (Chionoectes opilio). I Observations on spermiogenesis and spermatophore formation in the vas deferens. Canadian J Zool 77: 440-450.

37. Dudenhausen EE, Talbot P (1983) An ultrastructural comparison of soft and hard spermatophores from the crayfish Pacifastacus peninseula (Dana) Canadian J Zool 61: 182-194.

38. Bauer RT (1986) Phylogenetic trends in sperm transfer and storage complexity in decapods crustaceans. J Crust Biol 6: 313-325.

39. Subramoniam T (1991) Chemical composition of spermatophores in Decapod crustaceans. In Beuer, R.T and Martin, J.W. eds. Crustacean Sexual Biology. Columbia University Press, New York. USA 308-321.

40. Uma K, Subramaniam T (1979) Histochemical characteristics of spermatophore layers of Scylla serrata (Forskal) (Decapoda: Portunidae). Int J Invert Reprod 1: $31-40$.

41. Hinsch GW (1988) The morphology of the reproductive tract and seasonality of reproduction in the golden crab Geryon fenneri from the eastern Gulf of Mexico. J Crust Biol 8: 254-261.

42. Subramoniam T (1993) Spermatophore and sperm transfer in Marine Crustaceans. Advances in Marine Biology 29: 129-214.

43. Gardner C (1998) Larval and Reproductive biology of the giant crab Pseudocarcinus gigas, Ph.D. Thesis, University of Tasmania 1-351.

44. Hinsch G (1991) Structure and chemical content of the spermatophores and seminal fluid of reptantian decapods. In Bauer, R. and Martin, J. (Eds.): Crustacean Sexual Biology, Columbia University Press. New York 290-307.

45. Hinsch GW (1986) A comparison of sperm morphologies, transfer, and sperm massstorage between two species of crab, Ovalipes ocellatus and Libinia emarginata. Int J Invert Reprod Dev 10: 79-87.

46. Stewart MJ, Stewart P, Soonklang N, Linthong V, Hanna PJ, et al. (2010) Spermatogenesis in the blue swimming crab, Portunus pelagicus, and evidence for histones in mature sperm nuclei. Tissue Cell 42: 137-150.

47. Spalding J (1942) The nature and formation of the spermatophore and sperm plug in Carcinus maenas. Q J Microsc Sci 83: 399-423.

48. El-Sherief SS (1991) Fine structure of the sperm and spermatophores of Portunus pelagicus (L.) (Decapoda, Brachyura). Crustaceana 61: 272-279.

49. Anilkumar G, Sudha K, Subramoniam T (1999) Spermatophore transfer and sperm structure in the Brachyuran carb Metopograpsus messor (Decapoda: Grapsidae). J Crust Biol 19: 361-370.

50. Moriyasu M, Banhalima K (1998) Snow crabs, Chionoecetes opilio (Fabricius 1788) (Crustacea: Majidae) have two types of spermatophore: hypotheses on the mechanism of fertilization and population reproductive dynamics in the southern Gulf of St. Lawrence, Can J Nat Hist 32: 1651-1665.

51. Uma K (1978) Studies on comparative sperm morphology and spermatophores of crustaceans. M. Phil. Thesis, Madras University.

52. Uma K, Subramoniam T (1984) A comparative study on the spermatophore in Scylla serrata (Forsskal) (Decapoda: Branchyura) Clibanarius longitarsus (De Haan), Decapoda: Anomura). J Mar Biol Ass India 26(1\&2):103-108.

53. Benhalima K, Moriyasu M (2000) Structure and function of the posterior vas deferens of the snow crab, Chionoecetes opilio (Branchyura, Majidae). Inver Reprod Develop 37: 11-23.

54. Minagawa M, Chu, JR, Kudo M, Takashima F (1994) Male reproductive biology of the red frog crab, Ranina ranina, off Hachijyojima, Izu Island. Japan. Mar Biol 118: 393-401.

55. Sagi A, Khalaila I (2001) The crustacean androgen: A hormone in an isopod and androgenic activity in decapods. Amer Zool 41: 477-484.

56. CHARNIAUX-COTTON H (1954) [Discovery in, an amphipod crustacean (Orchestia gammarella) of an endocrine gland responsible for the differentiation of primary and secondary male sex characteristics]. C R Hebd Seances Acad Sci 239: 780-782.

57. Charniaux-Cotton H, Zerbib C, Meusy JJ (1966) Monographie de la glande androgene des crustaces superieurs. Crustaceana 10: 113-136.

58. Haefner PA (1976) Distribution, reproduction and molting of the rock crab Cancer irroratus say 1917 in the Mid-Atlantic Bight. J Natl His 10: 377-397. 
Citation: Soundarapandian P, Varadharajan D, Anand T (2013) Male Reproductive System of Blue Swimming Crab, Portunus pelagicus (Linnaeus, 1758). J Cytol Histol 5: 206. doi:10.4172/2157-7099.1000206

59. Campbell A, Eagles MD (1983) Size at maturity and fecundity of rockcrabs, Cancer irroratus, from the Bay of Fundy and southwestern Nova Scotia. Fish Bull (Wash. DC), 81: 357-362.

60. Corgos A, Freire $\mathrm{J}$ (2006) Morphometric and gonad maturity in the spider crab Maja branchydactyla: a comparison of methods for estimating size at maturity in species with determinate growth. J Mar Sci 63: 851-859.

61. Sukumaran KK, Neelakantan B (1996) Relative growth and sexual maturity in the marine crabs, Portunus (Portunus) sanguinolentus (Herbst) and Portunus (Portunus) pelagicus (Linnaeus) along the south-west coast of India. Indian J Fish 43: 215-223.

62. Lestang SD, Hall NG, Potter IC (2003) Reproductive biology of the blue swimming crab (Portunus pelagicus, Decapods: Portunidae) in five bodies of water on the west coast of Australia. Fish Bull 101: 745-757.

63. Hines $\mathrm{AH}$ (1982) Allometric constraints and variables of reproductive effort in branchyuran crabs. Mar Biol 69: 309-320.

64. Lopez Greco LS, Rodriguez EM (1998) Size at the onset of sexual maturity in Chasmagnathus granulata Dana, 1851 (Grapsidae: Sesarminae) a critical overall view about the usual criteria for its determination. Proc Fourth Int Crust Cong 675-689.

65. Pinheiro MAA, Fransozo A (1998) Sexual maturity of speckled swimming crab Arenaeus cribrarius (Lamark, 1818) (Decapoda, Brachyura, Portunidae), in the Ubatuba litoral, Silo Paulo State, Brazil. Crustaceana 71: 434-452.

66. Muino R, Fernandez L, Gonzalez-Gurriaran E, Freire J, Vilar JA (1999) Size at maturity of Liocarcinus depurator (Brachyura: Portunidae): a reproductive and morphometric study. J Mar Biol Ass UK 79: 295- 300.

67. Sampedro MP, Gonzalez-Guirrian E, Freire J, Muino R (1999) Morphometry and sexual maturity in the spider crab Maja squinado (Decapoda: Majidae) in Galicia, Spain. J Crust Biol 19:578-592.

68. Hartnoll RG (1974) Variation in growth pattern between some secondary sexual characters in crabs (Decapoda, Branchyura). Crustaceana 27: 131-136.
69. Oshiro LMY, Silva R, Silveira CM (1999) Rendimento de carne nos caranguejos Guaia, Menippe nodifrons Stimpson, 1859 e Guaiamum, Cardisoma guanhum Latreille, 1825 (Crustacea, Decapoda, Branchyura) da Baia de Sepetiba/Rj. Acta Biol Leopoldensia 21: 83-88.

70. Silva ZS, Oshiro LMY (2002) Aspectos reprodutivos de Goniopsis cruentata (Latreille) (Crustacea, Branchyura, Grapsidae) na Baia de Sepetiba, Rio de Janeiro, Brazil Revista Brasileira de zoologia 193: 907-914.

71. Hartnoll RG (1978) The determination of relative growth in crustacea. Crustaceana 34: 281-293.

72. Pillai KK, Nair NB (1973) Observation on the breeding biology of some crabs from south west coast of India. J Mar Biol Ass India 15: 574-770.

73. Sumpton WD, Smith GS, Potter MA (1989) Notes on the biology of the portunid crab Portunus sanguinolentus (Herbst) in subtropical Queensland waters. Australian J Mar Fresh Resear 40: 711-717.

74. Reeby J, Prasad PN, Kusuma N (1990) Size at sexual Maturity in the Male crabs of Portunus sanguinolentus and P. pelagicus. Fish Technol 27: 115-119.

75. Rasheed S, Mustaquim J (2010) Size at sexual maturity, breeding season and fecundity of three-spot swimming crab Portunus sanguinolentus (Herbst, 1783) (Decapoda, Brachyura, Portunidae) occurring in the coastal waters of Karachi, Pakistan. Fisher Res 103: 56-62.

76. Halawa J, Efrizal N (2006) Reproductive biology and larval rearing of blue swimming crab, Portunus pelagicus (Linnaeus, 1758). Ph.D. Thesis, University Putra Malaysia.

77. Hines AH (1989) Geographic variation in size at maturity in Brachyuran crabs Bull Mar Sci 45 (2): 356-368.

78. Fisher MR (1999) Effect of temperature and salinity on size at maturity of female blue crabs. T Am Fisher Soci 128: 499-506. 